\title{
Interrogating the Plausibility of Ideological Classification of Nigerian Society
}

\author{
Richard Taye Oyelakin \\ http://dx.doi.org//10.4314/ujah.v17i 2.1
}

\begin{abstract}
It is almost a theoretical truism that a society comprises different groups of people held together by common ideas, goals, and social-political and economic principles. These ideas, goals and principles precipitated different ideological groupings depending on the nature and supporting history of such society. Resulting from the differences in ideas, goals and principles in such a society, one ideological group is classified from the other. Consequently, talking about the organization of some Western societies namely, the United Kingdom, there are some diverse but sometimes competing ideological schools. Typically, we have the Conservative, the Liberal and the Radical Left. However, attempts are made to define African politico-economic structures along these foreign ideological classifications. This originates from the view that an ideological classification which originated and is working in some particular Western society must also work in typical African society. Whereas, the latter is not only different in its theoretical framework but also in its historical background. Consequently, this paper seeks to interrogate the justification of such classification of Nigerian society. The paper intends to submit that attempting to classify Nigerian politico-economic structure into these ideological frameworks is not only contradictory to the nature of our society, but also that such classifications are just conceptual acronyms for pseudo classes.
\end{abstract}




\section{Introduction}

There is bound to be a distortion of intellectual perception, especially when issues are not put into their correct perspectives. This distortion is perceived to be a problem in Nigeria when an attempt is made to define Nigerian society along ideological lines. It is thought that an ideological classification which originated and is working in some Western societies, because it has a peculiar supportive and enduring historico-theoretical background, must also work in African societies. Whereas, these African societies are not only different by their theoretical framework but also in their historical backgrounds. Discussion about the workability of these ideological dispositions in the African context is an attempt to impose a completely theoretically strange ideological edifice upon the African cultural structure. What this paper intends to argue is that attempting to classify Nigerian societal structure into ideological framework is not only unsupported by any plausible evidence but also strengthens the yoke of capitalism which is the direct progenitor of ideological classification.

In the first part, the paper intends to argue that ideological classification which characterizes the Western societies is strengthened by a theoretical history. In other words, these ideologies were not suddenly imported commodities to cuisine the effect of an economic turbulence. The second part intends to raise a reminder about the epochs in the history of the development of African societies, identify the variations in the theoretical frameworks which attended each epoch and then characterize the overall disposition inherent in the historic- theoretical build up. This will enable us to become conscious that the said ideological classification is not supported by African historical framework. To build on the foundation of part II, the third part shall attempt to identify 
what should be the main preoccupation of the Africans in this modern world of science and technology.

\section{Theoretical History of Western Ideological Classifications} According to Karl Marx's popular dictum "the history of every hitherto existing society is the history of class struggle", (Marx and Engels 1848). This dictum summarily presents a historical construction of a linear mode of transition among some five typology of societies. These societies are; communalism, slavery, feudalism, capitalism and then communism. The transition among these societies could be described as linear because basically it is the development in science and technology which produces the subsequent society. Each society is not only a development on the previous society, but also it is an advancement of and a build-up on the previous society. For instance, the invention of some crude implements changed the society from the stage of communal equality to the slavery relationship. Consequently, this development identifies and classifies the society into different classes. This, in effect, explains the relationship between the means of production, the mode of production and then the eventual superstructure. The superstructure, which is influenced by the means and mode of production, conversely characterizes the law, the norm, the music, the religion, the art, fashion, etc., which eventually governs and/or determines the culture, the means and the mode of production in the society.

These ingredients of the superstructure are powerfully used by a class of the society to determine the pace and the culture in society. All these ingredients are used to ensure that the rich in the society are perpetually protected. It must be so because while the poor proletarians are struggling to make ends meet, the rich are busy deciding what the best ingredients of the superstructure should be. The proletarians, 
who are the master of the machineries, and who have the number advantage, are also busy strategizing on how to break through from the economic hegemony of the capitalists with a view to changing the status quo. This is epitomized in the present day class conflict in any capitalist setting. This is the case from the slavery society through to the capitalist. In other words, the class ideology in the west has an enduring historical background. This is why the history of the Western societies is characterized by class struggle. Therefore, a class could be defined as a group of people which shares some common attributes such as occupying the same socialeconomic, political, and religious lines.

In this historical background, one thing which is persistently evident in historical dialectics is the disposition for struggle, change, and revolt. In other words, in this historical background, ideological classification is apparently supported. Consequently, the dominant disposition which ran through the historical epochs of the dialectics is that of the disposition of class struggle. And then "It follows, then, that as long as capitalism is still in business, Marxism must be as well", (Eagleton 2011: 2). It is observed that such a society at each historical stage has dispositional characteristics for ideological classification. Therefore, classifying British society and any other western societies, for instance, into these class categories is theoretically in congruence with their historical antecedents. As a matter of fact, it is evident that such a society could not but survive on such social-political structure.

It must be reasserted that such ideological classification is an attitude and such attitude is inherent in those societies and it has metamorphosed into their culture. Such societies have long existed on this culture to the extent that this cultural disposition is synonymous with their identity. The point which is being made is that the socio- 
political classification of British society into the Conservatives, the Liberals and the Radical Left is apparently consistent with and strongly supported by its historicotheoretic background. This explains why such society has existed, is identified with, and survived on such structural classification without raising any societal issue.

\section{African Historical Framework}

The main argument which is dominant in the previous part is that ideological classification in the West is strongly premised on the established and enduring cultural and historical foundation. It may be asked, does Africa have this historical foundation? This may point towards the answer;

At this point, we leave Africa not to mention it again. For it is no historical part of the world: it has no movement or development to exhibit ... what we properly understand by Africa is the unhistorical, underdeveloped spirit, still involved in the conditions of mere nature, which had to be presented here only as on the threshold of the world's history. (Hegel 1944: 99).

For Hegel, Africa is irrelevant when it comes to the issue of historical foundations. It might be inferred from this that what counts as significant historical background is not available in Africa. In fact, Osaghae sees Hegel as literally dismissing Africa as an irrelevant part of the world (Osaghae 1991: 23). Another way to buttress this point is that Karl Marx's historical dialectics does not apply to Africa. Well, this paper is skeptical about this point. However, this is the issue; in matters of historical significance, Africans must show that they have significant histories and which are actually relevant in matters of the world history. 
To forestall any possible objection, and to strengthen that point, Nkrumah asserted that "A colonial student does not by origin belong to the intellectual history in which the university philosophers are impressive landmarks" (Nkrumah 1970: 3). By significant historical background, it means historical foundation which may serve as a basis for sufficient intellectual theorizing. If by significant history which parallel Marxist dialectics, this sort of history may not be readily available in Africa. Africa was still at the main developmental stage when it came in contact with colonialism. The sort of background which is established in Africa is that mainly encapsulated in what Wiredu characterized as the evil of supernaturalism (Wiredu 1980: 5). However, this does not mean that everything about pre-colonial Africa was evil; far from it.

However, opinions of African scholars converge on the point that Africa's historical dialectics spanned three phases. These phases are; pre-colonial, colonial, and the post- colonial. According to scholars such as Nyerere, Nkrumah, Makinde, Bodunrin, Senghor, and others, each of these phases has its identifying characteristics. However African pre-colonial history has two distinct perspectives. A notable approach to African socio-cultural history is Nyerere's communalistic approach. For him, African pre-colonial African society was a typical description of communal relationship. For Nyerere, African society before the encounter with the colonialist was peaceful where equality, fairness, oneness, and love for one another were their identifying qualities. Such a society was a working society. "In traditional African society everybody was a worker" (Nyerere 1968: 4).

Hence in African socialism, there was no loiterer. This is because there is no socialism without work. Individuals earned a living through hard work. African socialist society took care of itself through the product of the labour of its 
workers. Each hierarchy of the society was taken care of from the equality organogram of the society. Each contributed to the society according to his/her strength or effort. The society gave to individual according his/her need. No cheating, no corruption. This explains the reason for the absence of millionaires in such society as this is a rare phenomenon. In fact, Nyerere foresaw a possibility of a contradiction in the term "socialist millionaire". Although a millionaire could be a socialist, it is not true in the other way round.

The attitude that ran in the society was that of familyhood, so Nyerere puts it, (Nyerere 1968: 12). The disposition propelled norms such as one should not cheat or defraud a fellow brother. This specified a non-individualistic and anticapitalist disposition. The force of this disposition did not allow Africans to be policed to keep their estate. No one told or taught the other person the need for hard work. Each person knew that no common wealth must be hoarded for personal interest within the commonwealth. No one felt discontented and then complained about the distribution pattern of the common wealth. The principles of equality and fairness were used in the wealth distribution. Consequently, distribution was done on a slogan such as 'from each according to his/her strength and to each according to his/her needs'. This outlook, however, must be balanced; it must be noted that traditional African societies was also fraught with its evils.

The second approach is the one upheld by Nkrumah. For him, African pre-colonial society was not as completely communal as Nyerere construed. For this approach, individualism and private ownership of property and class cleavage was not alien to Africans. This was epitomized by a series of internal crises and inter-communal struggles. 
In pre-colonial Africa, under conditions of communalism, slavery and feudalism there were embryonic class cleavages. ... This development has always been played down by reactionary observers, most of whom have maintained that African societies are homogeneous and without class divisions. (Nkrumah 1980: 22)

Besides, this approach opined that the Trans-Sahara and trans-Atlantic forms of slavery were built upon a slavery foundation already entrenched in Africa before these events. A not-far-fetched instance is the Efunsetan legend and her slavery activities in Ibadan kingdom. This presupposed that capitalistic characteristics stained African socio-political landscape before the European encounter. It must be reemphasized that traditional African societies were also filled with evils such as supernaturalism, lack of regard for human life and excessive use of power and authority. These manifested in activities such as using human beings as sacrifice to idols, unjustified and excesses use of positions and kingship authorities, etc. These actually decimated the supposed virtues of traditional societies. It appears that this is why Falola warns against "totalitarianism of the past and its cultures, and we have to be wary of those who present us with totalizing narratives of the past", (Falola 2007: 31). Not all was rosy in the traditional African past.

From this approach, it may not be true that the dominant disposition in pre-colonial African was that of classlessness, communalism, equality and fairness. This is because there were existing practices which negated such claim. From the embryonic nature of class cleavage in Africa, it might be retorted, even if there was such evils and capitalistic tendency in Africa, it was a very subtle one. This is because Nkrumah also established the fact that traditional African society was communal and egalitarian in nature. In 
fact, Nkrumah, in the opening paragraph of that chapter, also attests to the egalitarian nature of traditional African society, (Nkrumah 1970: 79). For instance, everyone was a worker. This means that no one stole another man's property because the prevailing and predominant societal attitude negated that. Instead of stealing, there was the Africans readiness to share materials with neighbours. In other words, theft was a recalcitrant experience which was vehemently frowned at.

To substantiate this point, it was possible for farmers and/or traders to display their farm products along a main pathway expecting the interested buyers to pick the desired product and drop its monetary equivalence. They did this without any fear of theft. Besides, traditional African society ran with cultural riches which find expression in each person being his brothers' keeper. This is underlined by the proverbial saying; Ojukan-nii-'bimo, igba-oju-niiwo, which may be literally translated as 'though a child is born by one person, that child is taken care of by so many people'. In African society, literally, a child is born to the society. A child was free to play, or eat anywhere without any fear of food poisoning. However, it may be argued that this characterized the primitive nature of such societies. The point is that even though there might be capitalistic tendency in African society, such was a very subtle one. The dominant attitude that existed in the society was more communalist than capitalist. Needless to say that this disposition is not consistent with the classification of Nigerian society into ideological classes. Ideological classification is supported by modern capitalist attitude which came with colonialism. An enduring historical background established Western societies into their ideological classifications.

The second phase witnessed an encounter with the European colonialism. During this period, there was a cultural collision between the western refined, scientific, and capitalist culture 
and the African primitive, non-scientific, and seemingly communalist culture. During this cultural collision or colonial superimposition on the African culture, many western cultural characteristics were introduced to, rather imposed on the African. The contents and concepts of African culture were condemned as magical, illogical, and primitive. The eventual sole aim of the colonialist was obviously exploitation. They were looking for cheap labour, markets for their finished products, and then converts so as to perpetuate their culture of oppression. They made converts out of Africans by introducing their religion and education. African were educated and taught religion so as to capture the Africans' mentally. In any case, this was successfully achieved. We are all testimony to the fact that Africans became alienated from their culture even in their land. However, this encounter influenced conflicting changes in Africa, yet the dominant idea forcefully introduced into African was capitalism. This attends to the issue of whether colonial experience for Africa is just an episode in the flow or an epoch. This question is partly raised by a prominent proponent of an episodic view, Ade-Ajayi:

... although the Europeans were generally masters of the colonial situation and had political sovereignty and cultural and economic dominance, they did not possess a monopoly of initiative during the colonial period ... in any long term view of African history, European rule becomes just another episode. In relation to wars and conflicts of people the rise and fall of empires, linguistic, cultural, and religious change and cultivation of new ideas and new ways of life, new economic orientiation ... in relation to all these, colonialism must be seen not as a complete departure from the African past, but as one 
episode in the continuous flow of African history, (Ade-Ajayi 1974: 230).

It is not out of the way to contribute and then make a position in the debate. Emphatically, colonial experience clearly marked a significant turning point in all the aspects of the African way of life. However, these significant effects of colonialism are conflicting. Arguing that colonialism is an episode is even counter productive. Pretentiously, it is capable of diverting attention from the indelible and significant effects of colonialism some of which obviously require attention. Colonialism is an epoch in African history; we must admit it and then face it. However, it is needless to belabor the arguments here. Makinde even prefers the term phase rather than epoch (Makinde 2007: 34-56).

Capitalism had to be introduced because it was pragmatic; it did the work. The colonialist did not directly introduce class ideology to Africans even though class ideology was an inherent offshoot of capitalism. Doing that however might be contradictory to and undermine their interest. The point is that, inherent in the all that colonialism introduced to Nigeria is ideological class. It consistently follows that class ideology is an offspring of capitalism. Besides, class ideology was also strengthened in Nigeria by the colonial students who returned from the West. Salami quoted Fashina as asserting that "ethnic antagonism ... are offshoots of the problem of capitalism", (Salami 2015: 1).

The third phase was post colonial. At this stage Africans were left to struggle with conflicting dispositions and attitudes, i. e. the communalist and capitalist dispositions, out of which they had to determine their survival. To pave a way out of the dilemma, several suggestions and recommendations were offered by some 
scholars. For Nyerere, the solution is that Africa should regain her socialist attitude of mind. For Nkrumah, Africa should synthesize the previous epochs and produce a formidable African society. This point is established in Nkrumah's view:

"...consciencism is the map in the intellectual terms of the disposition of the forces which will enable African society to digest the Western and the Islamic and the Euro-christian elements in Africa, and develop them in such a way that they fit into the African personality" (Nkrumah 1970:79).

For Senghor, there are some peculiar characteristics which differentiate the African from the rest of the world. These qualities are what he referred to as the real identity; the "africanese" of the Africans. It is these characteristics of African identity which Senghor wanted developed to create a modern and peculiar African society. Emerging from this was a mixed disposition. Attempts to, successfully, come up with a synthesized disposition has been the struggle of the Africans.

Neo-colonialism frustrates attempts to arrive at a synthesis of the three phases. Most African societies are neocolonial states. Significant mechanisms and policies which control the politico-economic spheres of African states are the prerogatives of the Western forces. This is underlined by Nkrumah that;

More often, however, neo-colonialist control is exercised through economic or monetary means. The neo-colonial state may be obliged to take the manufactured products of the imperialist power to the exclusion of competing product from elsewhere, (Nkrumah 1966: ix).

There is no doubt that this is the experience of most of the African states even till 2015. Therefore, most of the struggles 
in African countries centre on the quest for freedom from the hook of capitalism and how to re-gain African socialist or egalitarian attitude. But, this is against the neo-colonial forces. In this light, then, it might be safe to argue that if there is any class struggle, then there is a class ideology between the Western capitalist forces and the African Egalitarian attitude.

To this extent, Africans are struggling to re-gain their inherent egalitarian ideology. But I doubt if this is the sense in which the Left ideology is seen by the proponents. However, if Leftist ideology is described as an attitude which is structured to oppose a clearly defined African capitalist class, or to challenge an ideology which inherent part of African attitude, then it is sufficient to argue that this view is unsupported by any plausible historical evidence. More than that, such ideology has a sufficient surreptitious power to pitch African against their fellow brothers; the attitude abhorrent in Africa. This explains why Leftist ideology does not gain any significant recognition in Nigeria.

Therefore, the main question since independence for most African societies has been the question of survival in the face of the neo-colonial and poverty induced policies. For instance, since independence in 1960, the pendulum of Nigeria's politico-economic sphere has witnessed a perpetual swing. This swing is from two fronts. The first is a swing of government from the military to the civilian from 1960 till recent times. The second swing issues from the first. Unstable system of government has resulted in perpetual swing in governmental policies. Since then, each successive regime has failed to stabilize the country both economically and politically. It has always been a struggle to survive even as a state. The disposition which emerged out of this is a survival disposition. If we then wish to talk about ideology, the only ideology which has been perpetuated in the mind of African is the survival ideology. Therefore, from a survival disposition, 
an ideological classification of a society can not be justifiably implied.

In other words, if a surviving ideology characterizes the Left, then, the entire Nigerians may then be classified as the Left. Therefore, it is a common political phenomenon in Nigeria to claim to be socialist, progressive or even conservative, it is all for survival. A study into the Nigerian society shall underline this fact. Each person or group is only trying to find good means to survive. Therefore, in most cases, whatever the ideological name, it is just naming a survival ideology. This means that those names only enjoy conceptual existence and they are acronyms for a pseudo class which actually does not exist. For instance, what would make a prominent so called leftist to change ideology when confronted with the alluring seductions of the so called political leader, puppets of capitalism? There are examples to underline this. This means that, as far as Africa is concerned, people only uphold leftist ideology to establish a recognition which will eventually place them in the juicy corridor in the society. Such positions have shown the true picture of those examples of people that they are actually only seeking survival. This and some further evidences in the society strengthen the point that the only enduring ideology in Nigeria is the surviving ideology.

\section{Locating Africa in the Modern World of Science and Technology}

What has been established in the previous section is that ideological classification of African (Nigeria's society) societies is not only irreparably strange to Africa, as an offspring of capitalism, it is an enemy which is to be confronted and fought. It is another disguised weapon of neocolonial slavery. The main question which confronts Africans afresh is; how should Africa take advantage of the past epochs to shape her existence in this era of globalization 
engineered by science and technology, especially information technology? I think this is the main issue which confronts us anew. In this section, this paper shall direct attention to some of the heart-cry recommendations, suggestions, and instruction of some notable African scholars.

It is correctly observed that science and capitalism are the two dominant forces of contemporary African society, (Oloruntimehin 2007: 6). He raises the all- too pertinent question about the place of Africa in the new globalised world. For him, the main question which Africans must work towards is quoted in Amadou-Mahtar M'Bow (1985, 1992). Africa must work towards;

a form of modernization which is truly hers, taking her creative inspiration from the reinterpretation of the traditions of her past. She must seek renovation, freely assuming the responsibility for it and put to good use such rich cultural traditions and social and moral values as will enable her to inspire progress without self-betrayal and achieve change without self-adulteration, (Amadou-Mahtar M'Bow:1985, 1992) quoted by (Oloruntimehin, 2007: 8).

The main task of Africa's emancipation is not to excitedly but ignorantly agitate for ideological classification of African societies, but to seek a conscious cultural modernization which is peculiarly African. This inspiration must come from a re-conceptualization, reinterpretation and renovation of African culture. This reinterpreted and renovated culture should include a synthesis of the epochs. This is to engage the characteristics of each epoch in critical assessment with a view to identifying the useful components necessary to develop a more modern African culture. Of course not all is good or bad in each 
epoch. The outcome of such reinterpretation and renovation should produce a pragmatic culture. This is what should constitute the corpus of modern African culture. It is important to identify the need for conscious effort in this matter. This shall forestall self-betrayal, self-denial, and selfadulteration. This is a potent weapon to counteract the western forces, if successfully developed and applied.

This conscious attempt to develop a synthesized modern African culture is a sine qua non for Africa's emancipation. This synthesis includes being able to "comprehend and correct the mistake of the past" (Falola 2007: 40). This should consist, while not ignoring the histories from above, using histories from below as critical moderating voices on the borrowed ideas. (Falola 2007: 34). This is what shall enable Africans to "understand the West so that it can liberate itself from domination", (Falola 2007: 35). Conscious synthesis is necessary because in the modern world Africans "cannot escape being part of a global world", (Falola 2007: 35). This synthesis must include every aspect of African life. No stone must be left unturned.

Moreover, the synthesis shall influence and cause African rulers to be aware that the path to African progress and development does not lie in "being grafted to the ideas and institutions of their European, and Western former rulers" (Fanon 1968). For Falola, African should rise against the common enemy; the West and its capitalist tendencies. By implication, Africans should rise against the call to classify African societies along ideological lines. Ideological classification is an offspring of capitalism. I argue that as it is impossible to use Belzebub power to defeat Satan, so also it is impossible to use class ideology to defeat capitalism. However, if ideological class should be marked, then it means that all Africans are and must be Leftists seeking a change in capitalist status quo. 


\section{Conclusion}

The main point in this article is that ideological classification in the western societies is strongly supported by an enduring and historic-theoretical dialectics. Marxist dialectics drew from this strength. It is argued that Africa is not blessed with such enduring historical background. The paper argues that ideological classification is consistently deducible from the historical background of the western culture. But from Africa's historical experiences, conflicting cultures, it is impossible to successfully deduce ideological classification.

Besides, the paper argues that the only ideology which is consistent with Africa's experiences is struggling or surviving ideology. It is argued that if surviving and struggling ideology is synonymous with the Left, then all Nigerians are Leftists because each Nigerian is struggling to survive. Based upon this, the paper argues that the idea of ideological classification is an offspring of capitalism, the imported virus which corrupts African egalitarianism. The way out is to find means of weakening capitalism with its offspring in order to restore egalitarianism which, historically, is our nature. After all, the West, whose ideas we are trying to force on and implement in African societies are not mindful of Africa. Can anything good come out of Nazareth? Africa must work out modern African - egalitarianism. That which is our nature is that which is good for us. That is what we must adopt.

\section{Richard Taye Oyelakin \\ Department of Philosophy \\ Obafemi Awolowo University Ile-Ife, Nigeria}




\section{References}

Akinrinade S., Fashina D., Ogungbile D. O., and Famakinwa J. O. (eds) Rethinking the Humanities in Africa. Ile-Ife: Obafemi Awolowo University, 2007

Ajayi, Ade, "Colonialism: An Episode in African History". In

J. G. Roland and P. College (eds), Africa: The Heritage and the Challenge. Greenwich, Connecticut: Fawcett Publication, 1974

Amakiri, A. A. The Left in the Nigerian Politics. Lagos: Amkra Books, 1998

Eagleton, T. Why Marx was Right. London: Yale University Press, 2011

Falola, T. "Nationalizing Africa, Culturalizing the West, and Reformulating the Humanities in Africa". In Akinrinade S., Fashina D., Ogungbile D. O., and Famakinwa J. O. (eds) Rethinking the Humanities in Africa. Ile-Ife: Obafemi Awolowo University, 2007

Fanon, F. Black Skin, White Masks. London, 1968

Hegel G. W. F., The Philosophy of History. New York: 1944. Makinde, M. A. African Philosophy: The Demise of a Controversy. Ile-Ife: Obafemi Awolowo University, 2007

Marx, K. and Engels, F. Manifesto of the Communist Party; Chapter 1. MIA, 1848

Nkrumah, K. Class Struggle in Africa. London: Paraf Publication, 1980

Nkrumah, K. Neo-Colonialism: The Last Stage of Colonialism. New York: International Publishers Co., Inc., 1966

Consciencism: Philosophy and Ideology for Decolonization. New York: Library of Congress, 1970

Nyerere, J. K. "Ujamaa - The Basis of African Socialism". In Nyerere J. K. Ujamaa; Essays on Socialism. London: Oxford University Press, 1968 
Olorode, O. "The Labour Movement and the Politics of Liberation in Nigeria". In Salami Y. K., Famakinwa J. O. and Fasiku G. (eds) Nationalism and Economic Justice in Nigeria. Ile-Ife: Obafemi Awolowo University, 2015

Oloruntimehin, B. O. "Rethinking Humanities Scholarship in Africa”. In Akinrinade S., Fashina D., Ogungbile D. O., and Famakinwa J. O. (eds) Rethinking the Humanities in Africa. Ile-Ife: Obafemi Awolowo University, 2007

Osaghae, Eghosa E. "Colonialism and African Political Thought". Ufahamu: A Journal of African Studies. 19 (2-3) (1991): 22-38

Roland, J. G. and College, P. (eds), Africa: The Heritage and the Challenge. Greenwich, Connecticut: Fawcett Publication, 1974.

Salami, Y. K. "Capitalism, Economic Inequality and National Liberation in Fashina's Philosophy". In Salami Y. K., Famakinwa J. O. and Fasiku G. (eds) Nationalism and Economic Justice in Nigeria. Ile-Ife: Obafemi Awolowo University, 2015

Salami Y. K., Famakinwa J. O. and Fasiku G. (eds) Nationalism and Economic Justice in Nigeria. Ile-Ife: Obafemi Awolowo University, 2015

Senghor, L. S. On African Socialism. New York: Praeger, 1964 Wiredu, K. Philosophy and an African Culture. Cambridge: Cambridge University Press, 1980 